Please cite this article as:

Urbinati A, Chiaroni D, Chiesa V, Franzò S and Frattini F (2019).

How Incumbents Manage Waves of Disruptive Innovations: an Exploratory Analysis of the Global Music Industry.

International Journal of Innovation and Technology Management. vol. 16 (1), pp. 1-23.

(DOI: https://doi.org/10.1142/S0219877019500068) 


\title{
HOW INCUMBENTS MANAGE WAVES OF DISRUPTIVE INNOVATIONS: AN EXPLORATORY ANALYSIS OF THE GLOBAL MUSIC INDUSTRY
}

\begin{abstract}
Innovation scholars have paid special attention on the managerial approaches that incumbents should adopt to promptly respond to the emergence of disruptive innovations. These approaches include, among the others, the use of open innovation or the establishment of ambidextrous organizations. However, this body of research has not analysed how incumbents use these approaches over time, although they are very often confronted with waves of disruptive innovations that cyclically take place along the lifecycle of an industry. This paper looks into this issue through a historical analysis of the global music industry. For each of the three waves of disruptive innovations that have hit this industry over the last fifteen years (i.e., digital music distribution, permanent digital download and music streaming), we analyse the reactions of incumbents in terms of managerial approaches they adopted to respond to the emergence of the disruptive innovation. Therefore, we develop a model suggesting how incumbents evolve over time their responses to cycles of disruptive technological changes.
\end{abstract}

Keywords: innovation management, disruptive innovation, disruptive technological changes, incumbents, music industry.

\section{Introduction}

In the last two decades, innovation scholars have paid special attention to the concept of disruptive innovation (see, e.g., Christensen, 1997; Christensen and Overdorf, 2000; Yu and Hang, 2009), an innovation process that deeply changes the rules of competition in a given industry and brings new companies to top ranks of that industry by disrupting the established position of incumbents. More recently, some other scholars (see, e.g., Downes and Nunes, 2013) have highlighted the growing impact of this phenomenon due to the enabling effect of digital technologies. Indeed, many firms today use digital technologies to accelerate the development of disruptive products or services and to reach global markets in record times (see, for example, Kohler et al., 2009; Yoo et al., 2012; Hylving, 2014; De Massis et al., 2016).

According to the disruptive innovation model (Christensen, 1997), many large companies fail to stay at the top of their industries when disruptive innovations enter established markets. This because disruptive innovations have some characteristics which make them unattractive for established companies, and in particular: (i) disruptive products/services are simpler and cheaper, consequently they generally promise lower margins, not greater profits; (ii) they are first commercialized in emerging and niche markets; (iii) established companies' most profitable customers generally do not want products/services based on disruptive innovations.

Following the seminal study of Christensen (1997), many scholars have tried to refine the initial definition of disruptive innovation, trying to differentiate this concept in different typologies and contexts, i.e. "technological" disruption, "radical product" disruption and "business-model" disruption (see, e.g., Danneels, 2004; Markides, 2006). However, as highlighted by Wessel (2016), most scholars today agree in considering an innovation as disruptive when it is simultaneously (i) "cheaper, from a 
customer perspective; (ii) more accessible, from a usability or distribution perspective; (iii) based on a business model with structural cost advantages, relative to existing solutions".

In addition, existing literature suggests that newcomers are usually disruptors, while incumbents are often unable or unwilling to invest in disruptive innovations and promptly respond to their threat. In fact, several examples of incumbents that succeeded in responding to a disruptive innovation exist (see, for example, Danneels, 2004, Bergek et al., 2013), thanks to the development of dedicated strategic and organisational approaches. Examples of these approaches are the creation of ambidextrous organisations (Rotemberg and Saloner, 2000; O'Reilly and Tushman, 2004; Birkinshaw and Gibson, 2004) or the opening of innovation process boundaries to external contribution, i.e., the so-called open innovation (Chesbrough, 2005; West and Gallagher, 2006a, 2006b; Lichtenthaler, 2008), both in the inbound and outbound perspectives, such as the establishment of spin-offs as possible solutions to pursue disruptive innovation opportunities (Yu and Hang, 2009).

However, this body of research, although rich in terms of managerial implications, has not studied how incumbents develop and change over time their responses to the emergence of disruptive innovations. Indeed, very often, incumbents are confronted with waves of disruptive innovations, which cyclically take place during the lifecycle of an industry (see, e.g., Moreau, 2013). Therefore, understanding whether and how the response of incumbents to the emergence of disruptive innovations change over time, along different waves of disruptive technological changes, is a very timely and relevant topic to be addressed, and it would help overcome the limitations that the existing, cross-sectional approaches, face with.

Therefore, the aim of this paper is to investigate whether and how the development and implementation of these responses follow a path that evolves over time as a firm is confronted with different waves of disruptive innovations that cyclically take place in a given industry.

Through an exploratory analysis, we attempt to shed light on a relevant although under-researched innovation management issue and inform future research into this field of study. In particular, not only innovation scholars will benefit from this study, which contributes to the lively academic debate on how firm-level managerial responses to disruptive innovations are adopted over time, but also managers with responsibilities for innovation in those incumbents which are in search for approaches to survive to the threats of disruptive innovations.

The paper looks into this issue by conducting a historical analysis (Gottschalk, 1969) of the global music industry. The choice to focus on this industry arises from the high number of technological discontinuities that occurred in a relatively short time-period, since the diffusion of the Internet, personal computers, digital mobility and broadband connections (Moreau, 2013; Lamont, 2013; Brustein, 2014; Dredge, 2014; Cookson, 2015; Garrahan, 2015; Witt, 2015; Gapper, 2015; Garrahan and Bradshaw, 2015; Bradshaw and Bond, 2015; Bradshaw and Garran, 2015; Richter, 2015; Dredge 2015; Gauthier-Villars, 2015; Karp, 2016). In this analysis, we identify different waves of disruptive innovations that have hit this industry over the last fifteen years (i.e. digital music distribution, permanent digital download and music streaming). For each wave of disruptive innovation, we will identify how incumbents have responded to the threat and develop a model suggesting how these firms develop over time managerial approaches to respond to disruptive technological changes.

The remainder of the paper is organized as follows. Section 2 gives a brief overview of the existing literature. Afterwards, we summarize in Section 3 the results of our historical analysis and, then, discuss the main findings in Section 4. Finally, we conclude in Section 5 by highlighting the main implication of our study and identifying avenues for future research.

\section{Literature review}

Innovation scholars have paid special attention to the managerial approaches that incumbents should develop to manage the threat of disruptive innovations. Such approaches can be divided in two following 
steps: (i) the detection of a disruptive innovation; (ii) the response to the emergence of a disruptive innovation.

Regarding the former, one of the main issue in detecting disruptive innovations concerns the approaches used to forecast the market acceptance of new products or services (Bower and Christensen, 1995). Incumbents usually involve mainstream customers to test the market acceptance of their innovations. However, since disruptive innovations do not usually satisfy the current needs of such customers, incumbents are typically encouraged to overlook or abandon those innovations. The same scholars (Christensen and Bower, 1996) emphasize this aspect, highlighting how much damaging becomes this approach for incumbents, because it can slow their propensity to engage in the launch of disruptive innovations. The authors suggest avoiding mainstream customers as unique judges in the evaluation process of new products or services and to involve external actors, such as suppliers or new potential customers.

In addition, Adner (2002), starting from the idea of performance oversupply (see, e.g., Christensen, 1997), highlight how the emergence of a "competitive disruption" happens when a firm continues to improve the performance of existing products along the requests of the mainstream users, causing a reduction of their marginal utility and willingness to purchase those products. In this case, mainstream users could prefer similar products with slightly worse performance, but also at lower price.

Moreover, Kostoff et al. (2004) highlight the importance of the involvement of external actors in the evaluation process of new products or services and the exploitation of managerial commitment to identify potential disruptions (see, also, Sull et al., 1997).

For what concerns the managerial approaches to respond to the emergence of a disruptive innovation, several authors (Ghoshal and Bartlett, 1994; Adler et al., 1999; Birkinshaw and Gibson, 2004) propose the adoption of contextual ambidexterity by incumbents to manage disruptive innovations, by promoting intrapreneurship among employees. It allows pursuing, within the same organizational unit, different businesses following significantly different routines and processes, which are "achieved in large part through the creation of a supportive context in which individuals make their own choices about how and where to focus their energy". Accordingly, the ambidextrous contextual approach allows the exploitation (of the current business) and the exploration (of the disruptive business) by using behavioral and social means (Andriopoulos and Lewis, 2009).

In addition, as proposed by several authors (Bower and Christensen, 1995; Christensen, 1997; O'Reilly and Tushman, 1996; Rotemberg and Saloner, 2000; Birkinshaw and Gibson, 2004), incumbents can develop business units specifically dedicated - so-called structural ambidextrous organizations - to manage disruptive innovations. The creation of an independent business unit, separated from the traditional business of the firm, typically favors the application of a completely new business model and the development of new organizational routines, which are required to successfully develop and bring to market a disruptive innovation. Similarly, Christensen and Overdorf (2000) underline the importance to create new business units, separated from the traditional business of a firm, or to spin-out an independent organization to detect or react to a disruption.

Other scholars, such as Kostoff et al. (2004), agree with the need of a better exploitation of internal capabilities through the creation of dedicated teams, instead of the establishment of more structured organizational entities such as independent business unit.

Finally, several authors (such as Chesbrough, 2005, 2010; West and Gallagher, 2006a, 2006b; Lichtenthaler, 2008; Chiaroni et al., 2010; Bogers, 2011) advance that open innovation allows incumbents to quickly and efficiently manage disruptive innovations, when it entails absorbing external knowledge and technologies (outside-in or inbound open innovation) to accelerate the scouting and development of new products, especially if they are disruptive in nature. In particular, open innovation can be implemented through different organizational modes (Chiesa and Manzini, 1998), such as (i) networks with external partners (such as R\&D co-operations, strategic alliances, vertical and horizontal 
collaborations); (ii) licensing in/out, or in other words, the acquisition/selling of the right to use a specific asset; (iii) spinning in/off, on the basis that companies can either acquire a new technology by buying-out the firm which has developed it, or can create a spin-off in order to pursue outside the development of a technology invented inside; and (iv) licensing agreements, distribution/supply arrangements and R\&D partnerships (Chesbrough, 2004; Pénin et al., 2011). This is particularly important to take into account when disruptive innovations require incumbents to adopt new resources and assets from outside and reshape their business model (Christensen, 1997; Birkinshaw and Gibson, 2004).

Based on this short review of the literature, we summarize in Table 1 the main managerial approaches that incumbents should apply to detect and respond to the threat of disruptive innovations.

Table 1: The managerial approaches required to respond to the threat of disruptive innovations.

\begin{tabular}{|l|l|}
\hline $\begin{array}{l}\text { MANAGERIAL APPROACH TO DETECT A DISRUPTIVE } \\
\text { INNOVATION }\end{array}$ & REFERENCES \\
\hline $\begin{array}{l}\text { Avoid mainstream customers as unique evaluators of new products } \\
\text { or services }\end{array}$ & $\begin{array}{l}\text { Bower and Christensen (1995) } \\
\text { Christensen and Bower (1996) } \\
\text { Christensen (1997) } \\
\text { Adner (2002) }\end{array}$ \\
\hline $\begin{array}{l}\text { Exploit managerial commitment to evaluate potential disruptions } \\
\text { MANAGERIAL APPROACH TO RESPOND TO A }\end{array}$ & $\begin{array}{l}\text { Sull et al. (1997) } \\
\text { Kostoff et al. (2004) }\end{array}$ \\
\hline $\begin{array}{l}\text { Build contextual ambidextrous organizations } \\
\text { RIVERE INNOVATION }\end{array}$ & $\begin{array}{l}\text { REFEShal and Bartlett (1994) } \\
\text { Adler et al. (1999) } \\
\text { Birkinshaw and Gibson (2004) } \\
\text { Andriopoulos and Lewis (2009) }\end{array}$ \\
\hline $\begin{array}{l}\text { Exploit internal capabilities through the creation of dedicated teams } \\
\text { Create structural ambidextrous organisations (by creating new } \\
\text { business units, separated from the traditional business of a firm, or } \\
\text { by spinning-out an independent organization) }\end{array}$ & $\begin{array}{l}\text { Christensen and Overdorf (2000) } \\
\text { Kostoff et al. (2004) }\end{array}$ \\
\hline $\begin{array}{l}\text { Bower and Christensen (1995) } \\
\text { Christensen (1997) }\end{array}$ \\
$\begin{array}{l}\text { O'Reilly and Tushman (2004) } \\
\text { Rotemberg and Saloner (2000) } \\
\text { Christensen and Overdorf (2000) } \\
\text { Birkinshaw and Gibson (2004) }\end{array}$ \\
\hline
\end{tabular}

Consistently with the research question declared in the Introduction section, in the rest of the paper we only focus on the managerial approaches adopted by incumbents to respond to the waves of disruptive innovations that cyclically have occurred in the global music industry in the last fifteen years.

\section{Methodology}

From an empirical point of view, the paper studies how incumbents manage waves of disruptive innovations that cyclically take place during the lifecycle of an industry through a historical analysis (Gottschalk, 1969). Information gathered from published sources about the emergence of the main disruptive technological changes introduced in the music industry during the last fifteen years was analysed. Historical analysis relies on information collected at the time when these innovations appeared in the industry.

The choice to focus on the music industry arises from the high number of technological discontinuities that occurred in this sector, since the diffusion of the Internet, personal computers, digital mobility and broadband connections (Moreau, 2013; Lamont, 2013; Brustein, 2014; Dredge, 2014; Cookson, 2015; Garrahan, 2015; Witt, 2015; Gapper, 2015; Garrahan and Bradshaw, 2015; Bradshaw and Bond, 2015; Bradshaw and Garran, 2015; Richter, 2015; Dredge 2015; Gauthier-Villars, 2015; Karp, 2016). 
The aim of this paper is to highlight whether and how incumbents used different approaches to manage subsequent waves of disruptive innovations over time. Therefore, we identified the firm-level managerial approaches that incumbents adopted to manage waves of disruptive innovations that have hit the global music industry over the last fifteen years, to investigate if the implementation of these approaches followed a path which evolved over time along the different disruptive innovations that characterized the music industry globally.

First, a panel of six experts of the music industry was assembled to identify the main waves of disruptive innovations. In particular, three of them were operators in record companies and the other three were professors of innovation with research interests in the music industry. Afterwards, through the historical analysis, we identified the managerial approaches that main incumbents (i.e., the ones with the largest market share) adopted to manage these waves of disruptive innovations. In this phase, we analysed as primary sources journals, magazines and reports that have dealt with the main technological changes occurring in the global music industry. In particular, an average of hundred sources of information were gathered and analysed for each wave of disruptive innovation, for over three hundred sources. The choice to select more articles for each wave of disruptive innovation facilitated both single-case study analysis and cross-case comparisons. In addition, a content analysis (Weber, 1990) was performed on the collected material, to cluster the information contained in the selected documents. The most helpful and frequently referenced sources of information were Bloomberg, Business Insider, Forbes, Fortune, The Economist, The Financial Times, The Guardian, The New York Times, and The Wall Street Journal, which were searched using professional full-text journal databases such as InfoTrac and LexisNexis. To select and accept the sources of information, we applied the control criteria for historical analysis suggested by Golder and Tellis (1993) in their work, which are (i) competence, (ii) objectivity, (iii) reliability, and (iv) corroboration.

An in-depth description of the waves of disruptive innovations analysed in the paper is reported in the following section.

\subsection{Recent history of the global music industry}

The music industry has faced several changes in recent years. In 2014, the industry (\$ 15 billion revenues) saw for the first time in its history revenues from physical channels (sales of CDs) equalizing revenues from digital channels (sales of songs through operators like iTunes, subscriptions to music streaming services such as the one provided by Spotify or ad-supported music streaming services such as the one provided by YouTube or VEVO). This result was possible thanks to the growth of $6.9 \%$ in revenues from digital channels in 2014 over the previous year, reaching $\$ 6.9$ billion (46\% of the total revenues of the industry), and becoming the first distribution channel in five of the top ten global markets ${ }^{1}$. This situation resulted mainly from the growth in the number of users of streaming services, whose associated revenues grew dramatically $(+39 \%$ over the previous year). On the other hand, purchases of songs via digital channels have recorded a substantial stability compared to 2013. The sector of digital streaming has enabled realities such as Spotify and Deezer to increase its user base through a global expansion. Within the field of streaming music in 2014, we have also seen significant changes due to the entry in the field of companies like Google and Apple. In particular, in November 2014 Google launched its service Music Key, while Apple, with the acquisition of Beats, gained the control of the Beats Music service, which during 2015 was converted into Apple Music. On the other side, the physical distribution channel suffered a decline in sales, from $60 \%$ of revenues of the entire music industry in 2011 , to $46 \%$ in 2014 . Moreover, if we compare 2014 with 2013 there is a decrease of $8.1 \%$ in revenues over the previous year.

Although each country present specific characteristics related to the evolution of the music industry, major changes have occurred in the US market, which accounts for about $50 \%$ of the total revenues worldwide. In particular, in the US market (see Table 2) after a decline of $44 \%$ of the market between 2005 and 2010, a substantial revenues stabilization has occurred from 2010 onwards. During the five-year period 2010-

\footnotetext{
${ }^{1}$ The top 10 music markets worldwide include: United States, Japan, Germany, United Kingdom, France, Australia, Canada, South Korea, Brazil and Italy.
} 
2014 , the trend that has led to a decline of $88 \%$ of the physical market $(-35 \%$ reported in the period 2010 2014) was largely offset by the increase in revenues associated with the digital supports. The latter, indeed, in the period 2010-2014, saw an increase of 52\% of revenues. The digital market, including revenues generated by both the permanent digital downloads and streaming, has developed about $\$ 4.51$ billion in 2014, accounting for $66 \%$ of all revenues generated in the Music Industry. This figure was about $45.7 \%$ in 2010 and $9.5 \%$ in 2005.

Table 2: Trend of revenues from digital and physical channel in the US industry.

\begin{tabular}{|c|c|c|c|c|c|c|c|c|c|c|}
\hline & $\mathbf{2 0 0 5}$ & $\mathbf{2 0 0 6}$ & $\mathbf{2 0 0 7}$ & $\mathbf{2 0 0 8}$ & $\mathbf{2 0 0 9}$ & $\mathbf{2 0 1 0}$ & $\mathbf{2 0 1 1}$ & $\mathbf{2 0 1 2}$ & $\mathbf{2 0 1 3}$ & $\mathbf{2 0 1 4}$ \\
\hline $\begin{array}{c}\text { Revenues from } \\
\text { digital channel } \\
\text { (mln \$) }\end{array}$ & $1,101.8$ & $1,636.8$ & $2,386.3$ & $2,721.7$ & $2,972.6$ & $2,965.7$ & $3,555.6$ & $4,052.7$ & $4,361.5$ & $4,510.3$ \\
\hline $\begin{array}{c}\text { Revenues from } \\
\text { physical } \\
\text { channel } \\
\text { (mln \$) }\end{array}$ & $10,477.5$ & $9,269.7$ & $7,495.3$ & $5,474.3$ & $4,376.1$ & $3,518.5$ & $3,170.9$ & $2,584.3$ & $2,444.8$ & $2,272.2$ \\
\hline $\begin{array}{c}\text { Total revenues } \\
\text { (mln \$) }\end{array}$ & $11,579.3$ & $10,906.5$ & $9,881.6$ & 8,196 & $7,348.7$ & $6,484.2$ & $6,726.5$ & 6,637 & $6,806.3$ & $6,782.5$ \\
\hline
\end{tabular}

Hereafter, we summarize a brief history of the global music industry in the last fifteen years. By leveraging on the work of Moreau (2013), who analyses the main disruptive technological changes occurred in the music industry since its birth until the emergence of the Internet, we analyse the main waves of disruptive innovations since the diffusion of the Internet, personal computers, digital mobility and broadband connections.

\subsubsection{Digital music distribution and Napster}

The origin of the digital music distribution is associated to Napster, the company that created Napster MusicShare, a peer-to-peer (P2P) file-sharing program (i.e., a program that can directly connect computers within a network, with the aim to allow the communication and exchange of data among them) specialized in the exchange of music files encoded in MP3 format. The software was launched in June 1999, when Shawn Fanning and Sean Parker finished writing the code. This software had a revolutionary potential, facilitating - along with other programs such as Kazaa, Mopheus, Limewire, eMule and protocols such as BitTorrent - the transition of the music industry into digital music. The company offered its software and services free-of-charge to its users and allowed making available to the network of connected people the MP3 files residing in their hard drives. The program allowed to search for MP3 files inside folders shared by other users and, after creating an indexing of files, automatically managed the exchange of files across the Internet. These were the main features of Napster, although it included additional services such as a chat room available to users, who could discuss about topics to the music field. In addition, there was a space available to artists for offering users the information about their music. To access the community, users had to download the software Napster MusicShare from the company website, and then register to it by creating an account. Then, the user was asked to create a "user library", containing the contents to be shared with the community. When a user of the community sought a song, the servers were responsible for making available only the songs of the users online at that same time, thus allowing peer-to-peer exchange. The music industry incumbents opposed the Napster service, since its inception, because it represented a serious threat to their ability to create profits. On $6^{\text {th }}$ December 1999, the Recording Industry Association of America (RIAA) decided to take Napster to court with the charge ${ }^{2}$ of copyright infringement. Although the Napster service was offered to customers freeof-charge and it was regarded as illegal by incumbents, it was the first service to prove the digital channel as a viable option to distribute and commercialize music. Napster materialized several attempts to propose legal distribution systems of music, either made ex-novo by the holders of the rights (i.e. the incumbent recorded companies), or legalizing/sponsoring in various ways already existing services. Napster, which reached in the period of maximum expansion 80 million of registered users, demonstrated the ability to create a business based on digital distribution, an opportunity that was swiftly exploited by Apple with its iTunes Music Store service.

\footnotetext{
2 "In stark contrast to these legitimate companies, Napster is not developing a business around legitimate MP3 music files, but has chosen to build its business on large-scale piracy. Napster seeks to profit by encouraging and facilitating the distribution and reproduction of millions of infringing MP3 files. Moreover, by deliberately refusing to maintain any information about its users in order to make copyright enforcement next to impossible, Napster has created a virtual sanctuary where music piracy can and does flourish on a monumental scale." (A\&M Records Inc. v. Napster Inc.: 12).
} 


\subsubsection{Permanent digital download and iTunes Music Store}

Apple, with its iTunes Music Store (launched on April 28 ${ }^{\text {th }}, 2003$ ), represented the originator of the second wave of disruptive innovation, i.e. the permanent digital download. Apple was the first company to develop a consistent and profitable business model based on the digital distribution, speeding up the transition from the physical to the digital distribution of music contents. The success of iTunes, however, was accelerated by the evolution and expansion of digital mobility that allowed Apple to enlarge its user base. Apple iTunes allowed users not only to buy albums, but also individual pieces, for a rather low price (\$ 0.99 per song). The service brought a change in the way music was promoted and distributed: users could choose and buy just few songs of an album instead of the whole album. In this case, iTunes eliminated the concept of bundling (i.e., the explicit grouping of two or more products or services, which allows a company to sell them in packages at a predetermined price) that characterized the music industry until that moment. Another aspect that favored the success of the iTunes service derived from the complementarity between iTunes and the iPod music player. The booming sales of the iPod allowed Apple to create a community to whom it offered its services, initially limited only to the purchase of music through the iTunes Music Store. The success of iTunes was immediate with consumers (the user base accounted for more than 800 million users at the end of 2014). In the first week of activity of the store, more than one million songs were sold, while the milestone of 100 million was achieved in the next 15 months. Over time, Apple decided to introduce new products in the store. In 2005, following the iPod 5th generation, which enabled the playback of video contents, the company introduced the sale of films, videos, television episodes and video podcasts. Rental of films, however, was introduced only since 2008. A further change made to the iTunes service occurred in July 2008, when in conjunction with the release of iPhone OS2, Apple decided to create the section App Store to allow iPhone owners to download applications for their devices. The sale of iPhone applications in the store represented a new success for the company, and in record times the sale of applications became the major source of revenues for the iTunes platform. However, the revenues from the permanent digital download swiftly began to deteriorate due to the success of the music streaming services, mainly enabled by the diffusion of broadband connections.

\subsubsection{Music streaming and Spotify}

The origin of the music streaming service is associated to Spotify AB, the company that launched in October 2008 its music streaming service, named Spotify. This service has achieved considerable success, passing from 10 million customers on September 2010 (2.5 million paying subscribers) to 75 million active users in July 2015 (20 million premium users $\left.{ }^{3}\right)$ and it is still growing. This was surely enabled by the diffusion of broadband connections. Actually, Spotify has the leadership in the subscriptions of music streaming services, with a percentage of $37 \%$ of the market. Moreover, to finance its growth, the company raised \$ 526 million from financial investors, such as Goldman Sachs Group Inc., Baillie Gifford \& Co., Discovery Capital Management, Lansdowne Partners, Rinkelberg Capital and Senvest Capital. The heart of Spotify business model is its e-business platform, which provides a digital distribution of contents - a trend already used in the same sector by the iTunes service - with the difference to "hire" music contents and not to sell them. In addition, one of the main strategies used by Spotify to increase its user base was to ensure the maximum compatibility between its services and the various platforms. Indeed, Spotify is present on Windows, OSX and Android platforms. Moreover, without possessing proprietary devices, which allow for greater integration between hardware and service, the company created partnerships with manufacturers of hardware and audio speakers. Among the most important agreements of this type, the partnership with Sony to have the application inside the gaming console PS4. Further agreements have been undertaken with manufacturers of speakers such as Bang \& Olufsen or Sonos or smart TV manufacturers such as LG, Sony, Samsung and Philips. Spotify signed more relevant partnerships with mobile operators such as Vodafone Italia. Moreover, Spotify created a strategic partnership with Coca-Cola, which contributed with \$10 million to finance Spotify in exchange of the possibility for the two companies to exploit the brand of each other. Looking on the user base, Spotify is the company leader in the market of streaming with Apple and Deezer as second movers. Other companies, such as Tidal, still represent a niche product. It is possible to observe how the success

\footnotetext{
${ }^{3}$ Spotify offers two different types of service. The first one is the free one, where customers have free access to the music catalogue with limited functionalities and with the presence of ads. The second one is the premium one, which allow advanced functionalities and the possibility to download the music in local storages.
} 
of the new music streaming services is due to the "return" to the concept of bundling, in an "all you can eat" offering. In particular, users of these services, after paying a monthly subscription fee - are allowed to listen the music available in the catalogue.

Table 3 summarizes the waves of disruptive innovations - and their main characteristics - that have accompanied the history of the global music industry since the diffusion of Internet, personal computers, digital mobility and broadband connections over the last fifteen years.

Table 3: Waves of disruptive innovation - and their main characteristics - in the global music industry.

\begin{tabular}{|c|c|c|}
\hline YEAR & $\begin{array}{l}\text { WAVE OF } \\
\text { DISRUPTIVE } \\
\text { INNOVATION }\end{array}$ & MAIN CHARACTERISTICS \\
\hline $1990 \mathrm{~s}$ & Digital music distribution & $\begin{array}{l}\text { - Elimination of the music physical support that causes a } \\
\text { reduction of the production and distribution costs of music } \\
\text { contents } \\
\text { - The new digital channel causes a reduction of the } \\
\text { competitive advantage of the main incumbent record } \\
\text { companies (such as EMI, Sony Music, Universal Music } \\
\text { International, Warner Music Group and BMG) that controlled } \\
\text { the distribution of music contents through the physical } \\
\text { channel } \\
\text { - Independent record companies start to exploit the new } \\
\text { digital channel to distribute their music contents } \\
\text { - Entry of new digital distributors, such as Apple and Google, } \\
\text { with a completely different business model from the one of } \\
\text { incumbents } \\
\text { - Incumbents lost the control on digital music distribution, } \\
\text { especially the "direct contact" with end users, and become } \\
\text { content producers }\end{array}$ \\
\hline $2000 \mathrm{~s}$ & Permanent digital download & $\begin{array}{l}\text { - Unbundling of albums in favor of single songs that are } \\
\text { purchased by end users through the payment of the single } \\
\text { product } \\
\text { - The distribution and promotion of single songs is carried out } \\
\text { through the digital channel } \\
\text { - First users are mainly people willing to give up to high audio } \\
\text { performance for lower prices than physical music contents } \\
\text { - Possibility of listening a high number of single songs in } \\
\text { mobility } \\
\text { - Low distribution costs of music contents because they } \\
\text { become "digital goods" }\end{array}$ \\
\hline 2008 & Music streaming & $\begin{array}{l}\text { - The bundling of albums allows the access to an entire } \\
\text { catalogue of music contents at lower prices than permanent } \\
\text { digital download } \\
\text { - Passage from a possession to a "hire" of music contents } \\
\text { - Users are mainly people focused on the purchasing of a high } \\
\text { number of songs } \\
\text { - Access to an entire catalogue of music contents through the } \\
\text { payment of subscription fees or the viewing/listening of ads } \\
\text { (visual or audio advertising) }\end{array}$ \\
\hline
\end{tabular}

From the interviews with our panel of experts and the exploratory historical analysis we conducted, three waves of disruptive innovations, i.e. digital music distribution, permanent digital download and music streaming, gave a significant contribution for the evolution of the global music industry. In particular, they enabled the transition from a physical to a digital channel for the distribution of music contents.

Moreover, their characteristics effectively reflect those described in the literature by Christensen (1997) and Wessel (2016), considering that they simultaneously allowed: (i) the reduction of competitive advantage of incumbent companies that controlled the physical channel of music contents distribution; (ii) lower prices for end users to purchase music contents and lower costs for record companies to realize "digital products" compared to the traditional physical ones; and (iii) a completely different business model for new digital distributors compared to the ones of the incumbents. 
In the following section, we point out the reactions - in terms of adopted managerial practices - that incumbents pursued to face such threats.

\section{Findings and discussion}

From our exploratory historical analysis, it emerges that in the last fifteen years the global music industry evolved following three main waves of disruptive innovations, e.g. digital music distribution, permanent digital download and music streaming. Each disruptive innovation was promoted by a newcomer in the industry, as the frameworks developed by Christensen (1997) and Wessel (2016) suggest, i.e. Napster, Apple and Spotify, respectively.

Moreover, the empirical analysis shows that each disruption was enabled by some technological discontinuities, such as the Internet, personal computers, digital mobility and broadband connections. Interestingly, incumbents have developed and changed over time their managerial responses to the threat of these waves of disruptive innovations.

4.1.1. The first wave of disruptive innovation and the managerial responses from the incumbents In the first wave of disruptive innovation, Napster was recognized as the originator of the disruption resulting from digital distribution of music in 1990s. Through its peer-to-peer exchange program, Napster allowed users to recognize in the digital channel a new way to source of music contents. At that time, incumbents (such as BMG, Universal Music International (UMI), Sony Music, Warner Music Group and EMI) controlled the entire supply chain of the music industry, from contents production to the physical distribution of the music contents to the end users.

The new service negatively affected the sale figures of the incumbents in the physical music distribution channel. In addition, they lost part of their span of control in the delivery of music contents. Their reaction was twofold: first, they forced the ban of Napster through a lawsuit, which would lead to the elimination from the industry of the newcomer; second, the new way to access the music contents called incumbents to implement different strategies rather than the organizational approaches used for the traditional distribution. Indeed, incumbents tried to respond by creating dedicated business units to explore new potential opportunities offered by digital distribution (Afuah et al., 2002). For example, UMI initially merged two different business units, Universal Mobile and ELabs, in a new entity, named "New Technologies \& Media", to exploit the advantages that the distribution of digital goods (such as digital music), through the Internet channel, offered (Masson, 2013). Universal Mobile was focused on the production and distribution of music services, such as voicemail, short message services, video streaming, and downloads for mobile phones, while ELabs was established to develop new business opportunities and digital delivery systems for recorded music. The new entity worked on the creation of online stores through which they sold music in catalogues.

This response allowed incumbents to succeed in the short term, although in the long run they did not achieve sustainable results, because users did not have a single store to turn, but they were forced to turn to different platforms for creating their own music catalogue. The failure of this response and the exit of Napster from the industry, due to its ban, enabled the occurrence of a new disruptive innovation, i.e. the permanent digital download.

\subsubsection{The second wave of disruptive innovation and the managerial responses from the incumbents}

The control of the digital \music distribution by the incumbents was questioned by the second wave of disruptive innovation occurred in the music industry in 2000 s, i.e. the permanent digital download, which saw its ancestor in the iTunes Music Store by Apple. Even in this case, the incumbents suffered the impact of this disruption. First, they did not believe in the success of this new service. They initially replicated the same managerial approaches they adopted following the Napster's spread, until deciding to finally deliver their music contents through the iTunes Music Store, under the condition that Apple made the new service available only for Macintosh users (approximately 5\% of the potential market). The contract scheme concerning the distribution of revenues originated from the supply and sale of music contents through iTunes included a 30\% of the revenues for Apple and the other $70 \%$ for the 
incumbents. In this way, the incumbents created a partnership with Apple to become providers of music contents in the Apple's digital channel. However, this was in contrast with their traditional business model, including full control over the whole distribution chain. By doing so, they considered the iTunes as an alternative channel to their online stores, because it ensured a lower profit than the one guaranteed by their online stores. First, this allowed incumbents to maintain the control over the digital channel, but very soon, the situation changed as a result of the unexpected high level of sales of music contents through iTunes Music Store. It showed the value of Apple business model and pushed the incumbents to close their online stores and embrace the Apple platform more deeply. Consequently, incumbents renegotiated the initial contracts, including the possibility for Apple to sell music contents to Windows users too. Accordingly, the incumbents lost the control over digital distribution in favor of Apple, which became the main incumbent in the industry. In front of the new "disruptor", they remained content providers, sharing the revenues from the digital channel, as well as incumbents within the physical channel.

The success of the permanent digital download, with its main icon in the Apple's iTunes Music Store, enabled the emergence of a new disruptive innovation, i.e. the music streaming services, since users became so confident with the digital distribution to accept the transition from the possession to the "hiring" of music contents.

\subsubsection{The third wave of disruptive innovation and the managerial responses from the incumbents} The third wave of disruptive innovation was indeed due to the music streaming services since 2008 . Spotify, which represents the main icon of this new disruptive wave, disruptively slipped into the industry and undermined the position of incumbents in the digital distribution. Many users, attracted by this new competitor, opted to subscribe for a monthly subscription allowing unlimited listening of an entire music catalogue, instead of purchasing individual music contents from a store such as iTunes. The gradual transition from music purchasing to "hiring" reduced Apple's revenues in the music sector, bringing it to implement a change in its business model. Therefore, Apple first evaluated the launch of complementary services for iTunes instead of completely new services, to avoid cannibalization of sales of their existing services. Indeed, in November 2014, Apple introduced for its customers the iTunes Match service. Apple tried to create this streaming functionality by considering the increasing consumption of music in digital mobility through devices such as iPad, iPhone and iPod Touch. Customers who underwrote the service (by paying a fee of $\$ 24.99$ per year) had the possibility to upload their own music contents - regardless of the mode of acquisition - within the iTunes server to have them available at any time within the iCloud space. Whether a song was already present in the music catalogue of iTunes Music Store, Apple offered customers the opportunity to replace their songs with a betterquality version already available within the Apple server. Although Apple has never released data about the number of service subscribers, the success was rather limited. The reasons stem from the fact that iTunes foresaw the need for the user to own the song before uploading it on Apple's server, and not allowing, therefore, listening songs that they did not hold the possession. So, iTunes Match cannot be classified as a real "streaming" service, rather, as a purely cloud service. This observation seems to be confirmed by Apple itself, which classifies the service as an additional option to extend the benefits of the iCloud platform. Further evidence of this situation is the fact that Apple has always imposed a limit to the songs that each user could upload within iTunes Match. In addition, this issue differentiates this service from other music streaming services, which instead provide the access and the listening, in an unlimited way, of the entire catalogue available for the user. Therefore, the launch of the complementary product of iTunes Match was not sufficient for Apple to stop the decline in the music sales caused by a migration of users to the streaming services. Accordingly, the company decided in a second phase to cannibalize its iTunes service. Apple planned to develop its own music streaming service, and in May $28^{\text {th }}, 2014$, the company concluded the purchase of the company Beats Electronics for $\$ 3$ billion, by obtaining the control of the Beats Music streaming service. Some analysts agreed that the price paid by Apple to Beats was higher than the actual value of the acquired company, but through this deal, Apple could quickly close the gap that separated it from rivals such as Spotify, Deezer or Rdio. Through this external acquisition, Apple was able to take advantage from the agreements already signed by Beats with the record companies, and effectively to reduce time-to-market. In addition, the company had access to professionals who integrated within his team, as for example, Jimmy Iovine, the co-founder of 
Beats and a former music producer. After a year from the acquisition of Beats Music, Apple decided to transform the service in a way to be greater integrated within its own devices. On $8^{\text {th }}$ June 2015 , within the Apple WWDC (Apple Worldwide Developers Conference), the company announced the change of the service in Apple Music. The new service was created as a pay service with a monthly fee of \$ 9.99 and under two versions, the first one free-of-charge with ads (which means with the presence of advertising) and the second one with a payment, like the main competitor, i.e. Spotify.

Starting from its launch, Apple Music reached in less than one year and half around 20 million of users, allowing it to become competitive, but still second in the music streaming market, in front of Spotify.

\subsection{Discussion}

Figure 1 shows the three waves of disruptive innovations in the global music industry and the managerial responses adopted by the incumbents to deal with them.

The proposed model aims to highlight the managerial responses that incumbent companies adopted to respond to the waves of disruptive innovation that cyclically happened in the global music industry over the last fifteen years. For each wave of disruptive innovation, the managerial responses adopted by the incumbents allowed them to initially protect their competitive position in front of the newcomers (Teece et al., 1997). Moreover, the managerial approaches with which incumbents managed each disruption differ from one another, according to the virulence and the characteristics with which they diffused (Teece et al., 1997).

In responding to the first wave of disruptive innovation, i.e. the digital music distribution, a unique managerial response was adopted by the incumbents (except the lawsuit against the newcomer Napster, that cannot be considered as a managerial response), i.e. the establishment of permanent dedicated business units, enabled by structural ambidextrous organizations (Bower and Christensen, 1995; Christensen, 1997; O'Reilly and Tushman, 2004; Rotemberg and Saloner, 2000; Christensen and Overdorf, 2000; Birkinshaw and Gibson, 2004), involved in the creation of online stores through which incumbents sold music in catalogues.

To respond to the second wave of disruptive innovation, i.e. the permanent digital download, first incumbents replicated the same managerial approach they used for dealing with the first wave of disruptive innovation. However, they were not able to gain success in the short run, due to the incredible speed with which the disruptive innovation, i.e. Apples' iTunes Music Store, diffused into the market. As a consequence, a new managerial response was adopted by the incumbents, i.e. the establishment of a partnership with the newcomer itself (Chesbrough, 2005, 2010; West and Gallagher, 2006a, 2006b; Lichtenthaler, 2008; Chiaroni et al., 2010; Bogers, 2011), which represents an organizational mode to implement open innovation (Chiesa and Manzini, 1998). Although the contractual agreements changed over time according to the increasing diffusion of the new service, which allowed Apple to become the main incumbent in the digital music distribution, this appeared to be a more effective managerial response when incumbents were not able to manage in the short run the virulent diffusion of the new service by exploiting internal assets and capabilities.

Finally, to respond to the third wave of disruptive innovation, represented by the music streaming service, the main incumbent in the digital music distribution in 00's, i.e. Apple with its iTunes Music Store, first tried to respond with the creation of a complementary service - the iTunes Match - to add to its infrastructural platform of existing services. Because of the characteristics of the new disruptive technological change and of the virulence with which Spotify diffused into the market, the incumbent succeeded in competing with Spotify by taking advantage from the acquisition (Chesbrough, 2005, 2010; West and Gallagher, 2006a, 2006b; Lichtenthaler, 2008; Chiaroni et al., 2010; Bogers, 2011), which represents another organizational mode to implement open innovation (Chiesa and Manzini, 1998). In particular, the acquired company, i.e. Beats Electronics, had already in place a music streaming service similar to the one offered by Spotify. This managerial response allowed Apple to timely react to Spotify when it was able to reduce effectively its time-to-market. 


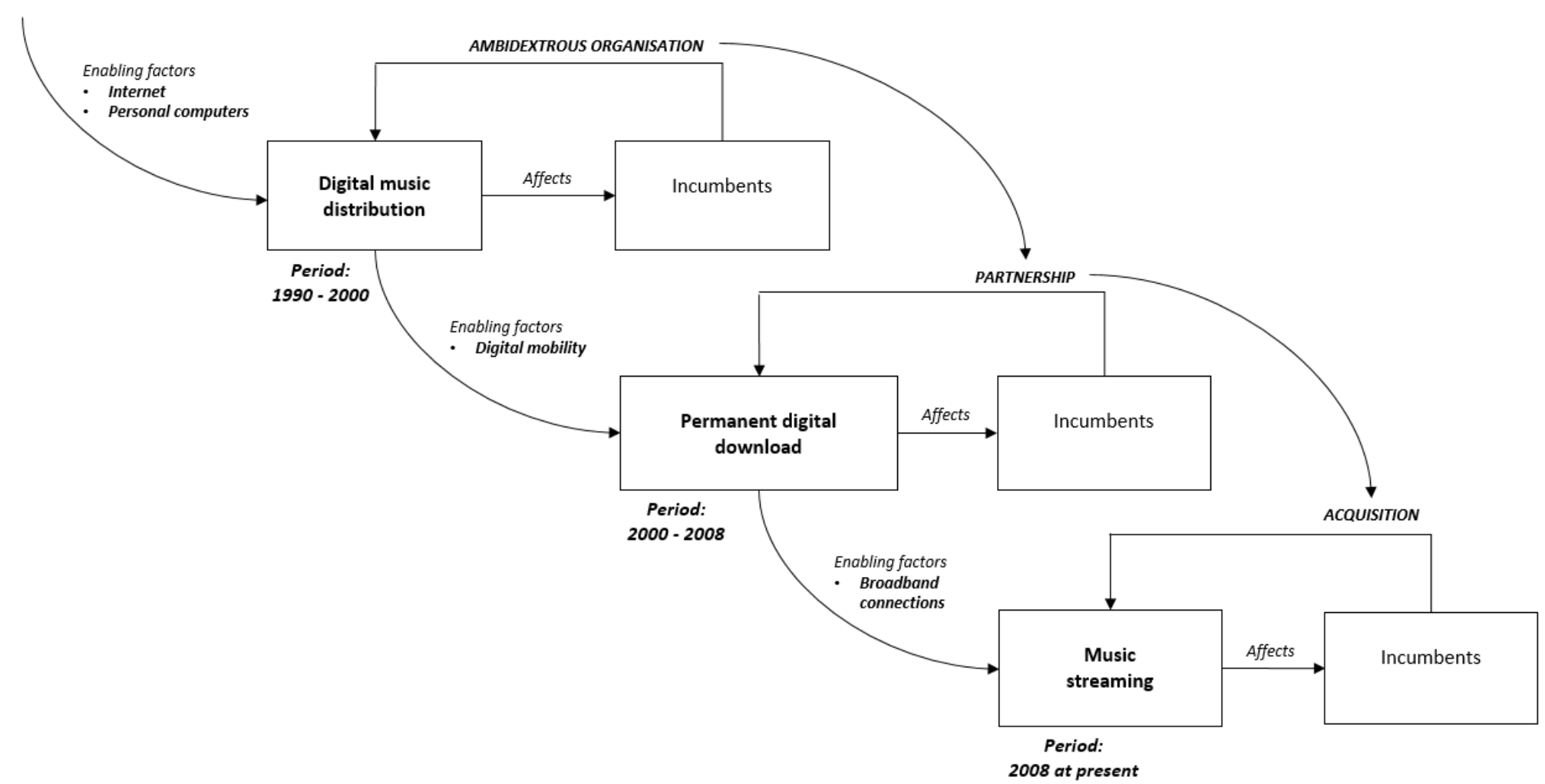

Figure 1: Waves of disruptive innovations in the global music industry and the managerial responses adopted by the incumbents 
From these observations, a path arises regarding the responses with which incumbents in the global music industry have answered to the threat of disruptive innovations' waves. These responses, indeed, evolve over time as a result of a path whereby incumbents primarily start to exploit their internal assets and capabilities (with the creation of permanent dedicated business units, i.e. structural ambidextrous organizations) (Bower and Christensen, 1995; Christensen, 1997; O’Reilly and Tushman, 2004; Rotemberg and Saloner, 2000; Christensen and Overdorf, 2000; Birkinshaw and Gibson, 2004), and then moved to more externally-oriented approaches (such as partnerships and acquisitions) (Chiesa and Manzini, 1998; Chesbrough, 2005, 2010; West and Gallagher, 2006a, 2006b; Lichtenthaler, 2008; Chiaroni et al., 2010; Bogers, 2011).

In particular, in the proposed scheme, the managerial approaches with which incumbents responded to the cyclical waves of disruptive innovations seem to follow a dynamic path dependence process (Vergne and Durand, 2010), which connects past and slower with future and faster responses of incumbents. In particular, incumbents seem to move from the exploitation of their internal resources and processes to more timely approaches when the following waves of disruptive innovations are faster, more subtle and unpredictable. This is even truer in a context such as that of the global music industry, a particularly turbulent technological context, where "time-to-market and timing are critical, the rate of technological change is rapid and the nature of future competition and markets difficult to determine" (Teece et al., 1997).

Accordingly, this process follows the condition of self-reinforcement of managerial approaches over time (Vergne and Durand, 2010), which is the continuous implementation of different, dynamic and faster managerial approaches that make incumbents more capable rather than the previous alternative path to quickly respond to faster, more subtle and unpredictable waves of disruptive innovations.

However, it is worth to highlight how the more the context is turbulent, i.e. the disruptive innovations are faster, more subtle and unpredictable, the more the managerial approaches adopted by incumbents are complex from an organizational point of view (Chiesa and Manzini, 1998). This is particularly interesting to point out when existing literature on disruptive innovation calls companies to adopt more flexible and less formal organizational structures (Bower and Christensen, 1995; Christensen, 1997). In fact, this apparent contradiction reflects the different viewpoints that later evolved in the disruptive innovation literature, where scholars suggest studying disruptive innovations through several perspectives, which embrace different articulations of the disruption, such as technology, radical product and business model, as well as the different contexts in which it diffuses (Markides, 2006; Yu and Hang, 2010).

\section{Conclusions}

The paper discusses how incumbents develop over time managerial approaches to respond to the threat represented by waves of disruptive innovations that cyclically take place during the lifecycle of an industry. This is an important issue to address in the field of disruptive innovations, to investigate whether and how the development and implementation of several managerial approaches follow or not a path, which evolves over time when incumbents are confronted with a flow of disruptive innovations that cyclically take place in the industry where they operate.

Through a historical analysis of the global music industry, we have highlighted the main waves of disruptive innovations over the last fifteen years (i.e., digital music distribution, permanent digital download and music streaming) and their main enabling factors (i.e., Internet, personal computers, digital mobility and broadband connections). 
Second, we analyzed the reactions of incumbents in front of these waves of disruptive innovations. We found that, for each wave of disruptive innovation, incumbents have implemented different managerial responses, with the following sequence:

i. Exploitation of internal managerial practices, enabled by structural ambidextrous organisations (Bower and Christensen, 1995; Christensen, 1997; O’Reilly and Tushman, 2004; Rotemberg and Saloner, 2000; Christensen and Overdorf, 2000; Birkinshaw and Gibson, 2004);

ii. Creation of partnerships, such as the establishment of relationships with specific actors operating in the value chain (Chiesa and Manzini, 1998; Chesbrough, 2005, 2010; West and Gallagher, 2006a, 2006b; Lichtenthaler, 2008; Chiaroni et al., 2010; Bogers, 2011);

iii. Acquisitions of other companies, in order to absorb external knowledge capital and innovative technology solutions (Chiesa and Manzini, 1998; Chesbrough, 2005, 2010; West and Gallagher, 2006a, 2006b; Lichtenthaler, 2008; Chiaroni et al., 2010; Bogers, 2011).

The empirical evidence suggests that the managerial responses to waves of disruptive innovations that cyclically take place within the lifecycle of an industry follow a dynamic path, which evolves over time as a consequence of the implementation of different, dynamic and faster managerial approaches by incumbents (Vergne and Durand, 2010). In particular, our proposed framework summarizes and explains how the shift from the adoption of past and slower with future and faster responses of incumbents is driven by the turbulence of the environment.

Through this paper, we aim to shed light on a relevant although under-researched innovation management issue and inform future research into the field of disruptive innovations. We think that innovation scholars can benefit from this study, which contributes to the lively academic debate on how firm-level managerial approaches to disruptive innovations are developed and implemented over time. In addition, we aim to provide useful tools, insights and examples to the managers with responsibilities for innovation and strategy in established companies, which are in search for managerial approaches to respond to the threats of disruptive innovations and new technological changes.

In particular, as far as the managerial perspective is concerned the paper brings to light interesting insights and implications. We highlight the risk to adopt internal managerial approaches, when dealing with waves of disruptive innovations that are faster, more subtle and unpredictable if compared with other technological changes previously appeared in a given industry. New disruptive technological changes could require the implementation of other managerial approaches, which are more timely and effective, such as the establishment of partnerships or acquisitions. In particular, these managerial approaches, mostly based on an external perspective, allow companies to access knowledge sources from outside, instead of developing from within the assets, capabilities and knowledge they need to compete into the market, implying a significant reduction in time-to-market and timing in front of new technological changes. This is particularly true, when incumbent companies are confronted with disruptive technological changes enabled on digital solutions, as in the case of the global music industry over the last fifteen years, which require thinking out of traditional processes, knowledge and capabilities - the same solutions that have allowed them to grow over time and to maintain the same business model over years.

We think that our contribution could invite managers and practitioners in charge for innovation activities to push the incumbent companies in which they operate towards a shaping and adaptation of their consolidated business model, even leveraging on different and dynamic managerial approaches, when facing with the emergence of new disruptive technological changes. 
Understanding whether and how the development and implementation of the managerial approaches to deal with waves of disruptive innovations depends on conditions of contingency, e.g. unexpected reactions by competitors, technological factors that enable disruptive changes or not forecasted market development, may be an interesting avenue for further research.

In addition, the findings of this research, due to the methodology that we used, cannot be generalized to any population of incumbents or industries. Accordingly, we believe that our model could be used to analyse disruptive technological changes that happen in other industries and the strategic reactions of incumbent firms. This could access the generalizability of our findings and discover similarities or differences with the managerial approaches adopted by other incumbents in other industries. 


\section{References}

1. Adler, P., Goldoftas, B. and Levine, D. (1999). Flexibility versus efficiency? A case study of model changeovers in the Toyota production system. Organization Science, 10, 43-68.

2. Adner, R. (2002). When are technologies disruptive? A demand-based view of the emergence of competition. Strategic Management Journal, 23(8), 667-688.

3. Afuah, A., Tucci, C.L., and Virili, F. (2002). Modelli di e-business, Ms Graw Hill.

4. Andriopoulos, C., Lewis, M.W. (2009). Exploitation-exploration tensions and organizational ambidexterity: Managing paradoxes of innovation. Organization Science, 20(4), 696-717.

5. Bergek, A., Berggren, C., Magnusson, T., and Hobday, M. (2013). Technological discontinuities and the challenge for incumbent firms: Destruction, disruption or creative accumulation? Research Policy, 42(6-7), 1210-1224.

6. Birkinshaw, J., and Gibson, C. (2004). Building ambidexterity into an organization. MIT Sloan Management Review, 47-55.

7. Bogers, M. (2011). The open innovation paradox: knowledge sharing and protection in R\&D collaborations. European Journal of Innovation Management, 14(1), 93-117.

8. Bower, J.L., and Christensen, C.M. (1995). Disruptive technologies: catching the wave. Harvard Business Review.

9. Bradshaw, T., and Bond, S. (2015). Apple rewrites app economics for media. The Financial Times.

10. Bradshaw, T., and Garrahan, M. (2015). Apple looks beyond iTunes with launch of its streaming service. The Financial Times.

11. Brustein, J. (2014). Napster: Music Sales Haven't Been the Same Since. Bloomberg.

12. Chesbrough, H. (2004). Managing open innovation. Research-Technology Management, 47(1), 23-26.

13. Chesbrough, H.W. (2005). Open innovation for understanding industrial innovation. Open Innovation: Researching a New Paradigm (Book), Oxford University Press, Ch. 1.

14. Chesbrough, H.W. (2010). Business Model Innovation: Opportunities and Barriers. Long Range Planning, 43, 354-363.

15. Chiaroni, D., Chiesa, V., and Frattini, F. (2010). Unravelling the process from Closed to Open Innovation: evidence from mature, asset-intensive industries. R\&D Management, 40(3), 222-245.

16. Chiesa, V., Manzini, R. (1998). Organizing for technological collaborations: a managerial perspective. $R \& D$ Management, 28(3), 199-212.

17. Christensen, C.M. (1997). The innovator's dilemma: when new technologies cause great firms to fail. Boston: Harvard Business School Press.

18. Christensen, C.M., and Bower, J.L. (1996). Customer power, strategic investment, and the failure of leading firms. Strategic Management Journal, 17(3), 197-218.

19. Christensen, C.M., and Overdorf, M. (2000). Meeting the Challenge of Disruptive Change. Harvard Business Review.

20. Cookson, R. (2015). Apple's deep pockets pose threat to Spotify in music battle. The Financial Times.

21. Danneels, E. (2004). Disruptive technology reconsidered: a critique and research agenda. Journal of Product Innovation Management, 21, 246-258.

22. De Massis, A., Frattini, F., and Quillico, F. (2016). What Big Companies Can Learn from the Success of the Unicorns. Harvard Business Review.

23. Downes, L., and Nunes, P. (2013). Big bang disruption: business survival in the age of constant innovation. New York, USA: Portfolio Penguin.

24. Dredge, S. (2014). Napster exec says labels 'short-sighted' for creating YouTube's music power. The Guardian.

25. Dredge, S. (2015). Spotify financial results show struggle to make streaming music profitable. The Guardian.

26. Eisenhardt, K.M., and Martin, J.A. (2000). Dynamic capabilities: What are they? Strategic Management Journal, 21(10-11) 1105-1122.

27. Gapper, J. (2015). 'How Music Got Free: What Happens When an Entire Generation Commits the Same Crime?', by Stephen Witt. The Financial Times.

28. Garrahan, M. (2015). Marty Bandier, CEO, Sony/ATV: Calling the tune. The Financial Times.

29. Garrahan, M., and Bradshaw, T. (2015). Apple launches new streaming service. The Financial Times.

30. Gauthier-Villars, D. (2015). Spotify Revenue Rises in 2014 but Still in Red on Heavy Investments. The Wall Street Journal.

31. Golder, P.N., and Tellis, G.J. (1993). Pioneer advantage: Marketing logic or marketing legend? Journal of Marketing Research, 30(2), 158-170.

32. Gottschalk, L.R. (1969). Understanding history: A primer of historical method. New York: Knopf. 
33. Ghoshal, S., and Bartlett, C.A. (1994). Linking organizational context and managerial action: The dimensions of quality of management. Strategic Management Journal, 15, 91-112.

34. Hylving, L. (2015). Competing Values in the Era of Digitalization. 48th Hawaii International Conference on System Sciences, 4161-4170.

35. Karp, H. (2016). Recording Industry Reports Revenue Increase Due to Streaming. The Wall Street Journal.

36. King, A.A., and Tucci, C.L. (2002). Incumbent entry into new market niches: the role of experience and managerial choice in the creation of dynamic capabilities. Management Science, 48(2), 171186.

37. Kohler, T., Matzler, K., and Füller, J. (2009). Avatar-based innovation: Using virtual worlds for real-world innovation. Technovation, 29(6), 395-407.

38. Kostoff, R.N., Boylan, R., and Simons, G.R. (2004). Disruptive technology roadmaps. Technological Forecasting and Social Change, 71, 141-159.

39. Lamont, T. (2013). Napster: the day the music was set free. The Guardian.

40. Lichtenthaler, U. (2008). Open Innovation in Practice: An Analysis of Strategic Approaches to Technology Transactions. Transactions on Engineering Management, 55(1).

41. Markides, C. (2006). Disruptive innovation: in need of better theory. Journal of Product Innovation Management, 23, 19-25.

42. Masson, G. (2003). UMI rethinks Online Plans. Billboard, 8, 6-21.

43. Moreau, F. (2013). The Disruptive Nature of Digitization: The Case of the Recorded Music Industry. International Journal of Arts Management, 15(2).

44. O'Reilly, C.A., and Tushman, M.L. (2004). The ambidextrous organization. Harvard Business Review, 82(4), 74-81.

45. Pénin, J., Hussler, C., Burger-Helmchen, T. (2011). New shapes and new stakes: a portrait of open innovation as a promising phenomenon. Journal of Innovation Economics \& Management, 1(7), 11-29.

46. Pinkse, J., Bohnsack, R., and Kolk, A. (2014). The Role of Public and Private Protection in Disruptive Innovation: The Automotive Industry and the Emergence of Low-Emission Vehicles. Journal of Product Innovation Management, 31(1), 43-60.

47. Richter, F. (2015). Spotify Has 60M Users But Only 1 in 4 Pays. Statista.

48. Rotemberg, J., and Saloner, G. (2000). Competition and human capital accumulation: A theory of interregional specialization and trade. Regional Science and Urban Economics, 30, 373-404.

49. Sull, D.N., Tedlow, R.S., and Rosenbloom, R.S. (1997). Managerial commitments and technological change in the U.S. tire industry. Industrial and Corporate Change, 6, 461-501.

50. Teece, D.J., Pisano, G., Shuen, A. (1997). Dynamic Capabilities and Strategic Management. Strategic Management Journal, 18(7), 509-533.

51. Vergne, J.P., Durand, R. (2010). The missing link between the theory and empirics of path dependence: conceptual clarification, testability issue, and methodological implications. Journal of Management Studies, 47(4), 736-759.

52. Weber, R.P. (1990). Basic content analysis. Newbury Park, CA: Sage.

53. West, J., and Gallagher, S. (2006a). Challenges of open innovation: the paradox of firm investment in open-source software. $R \& D$ Management, 36(3), 319-331.

54. West, J., and Gallagher, S. (2006b). Patterns of open innovation in open source software, in Open innovation: researching a new paradigm, H.W. Chesbrough, W. Vanhaverbeke, J. West (eds), New York: Oxford University Press.

55. Wessel, M. (2016). How Big Data is Changing Disruptive Innovation. Harvard Business Review.

56. Witt, S. (2015). Who will win the streaming wars? The Financial Times.

57. Yoo, Y., Boland Jr, R.J., Lyytinen, K., and Majchrzak, A. (2012). Organizing for innovation in the digitized world. Organization Science, 23(5), 1398-1408.

58. Yu, D., and Hang, C.C. (2009). A Reflective Review of Disruptive Innovation Theory. International Journal of Management Reviews, 12, 435-452. 